(5.) (E. Renjiug's

\title{
ge fammelte
}

3̧weiter Banb. 



\section{(5.) (5. Refjinth'}

\section{gefammelte Merlie}



3weiter Band.

$\mathbb{L} \mathfrak{e} \mathfrak{i} \mathfrak{p} \mathfrak{i} \mathfrak{g}$.

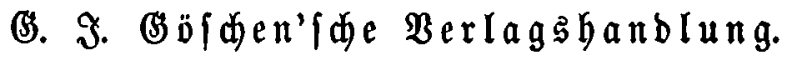

1864. 


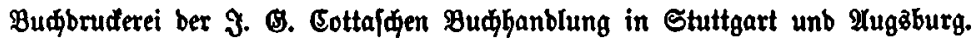

